\title{
Sago pith residue as alternative cheap substrate for fermentable sugars production
}

\begin{abstract}
Sago pith residue is one of the most abundant lignocellulosic biomass which can serve as an alternative cheap substrate for fermentable sugars production. This residue is the fibrous waste left behind after the starch extraction process and contains significant amounts of starch $(58 \%)$, cellulose $(23 \%)$, hemicellulose $(9.2 \%)$ and lignin $(3.9 \%)$. The conversion of sago pith residue into fermentable sugars is commonly performed using cellulolytic enzymes or known as cellulases. In this study, crude cellulases were produced by two local isolates, Trichoderma asperellum UPM1 and Aspergillus fumigatus, UPM2 using sago pith residue as substrate. A. fumigatus UPM2 gave the highest FPase, CMCase and $\beta$-glucosidase activities of $0.39,23.99$ and $0.78 \mathrm{U} / \mathrm{ml}$, respectively, on day 5 . The highest activity of FPase, CMCase and $\beta$-glucosidase by T. asperellum UPM1 was $0.27,12.03$ and $0.42 \mathrm{U} / \mathrm{ml}$, respectively, on day 7 . The crude enzyme obtained from A. fumigatus UPM2 using $\beta$-glucosidase as the ratelimiting enzyme (3.9, 11.7 and $23.4 \mathrm{IU})$ was used for the saccharification process to convert $5 \%$ (w/v) sago pith residue into reducing sugars. Hydrolysis of sago pith residue using crude enzyme containing $\beta$-glucosidase with $23.4 \mathrm{IU}$, produced by A. fumigatus UPM2 gave higher reducing sugars production of $20.77 \mathrm{~g} / \mathrm{l}$ with overall hydrolysis percentage of $73 \%$.
\end{abstract}

Keyword: Sago pith residue; Crude enzyme; Trichoderma asperellum UPM1; Aspergillus fumigatus UPM2; Saccharification 